\title{
PANDEMI COVID 19 DAN KEMISKINAN ; SUATU PRESPEKTIF TEOLOGIS KRISTEN
}

\author{
Yunus \\ Sekolah Tinggi Teologi Wesley Methodist Indonesia \\ hiphopman.0402@gmail.com
}

\begin{abstract}
When the COVID-19 virus became a pandemic, its impact was in almost all areas of life and was felt by many countries in the world. One of the impacts is an increase in the poverty rate. In Indonesia alone it is estimated that 1.2 million will be infected and will reduce the rate of economic growth by 1 - 4 percent then also increase the poverty rate from 9.2\% in September 2019 to $9.7 \%$ by the end of 2020. This means that there will be 1.3 million of people who will fall into poverty, with the worst projection the poverty rate will be $12.4 \%$ and this means that 8.5 million people will fall into poverty. In the Bible, poverty has been mentioned a lot, poverty in the OT is a bad and cruel condition that insults human dignity and is against the will of God. Whereas in the NT the concept of poor is understood as a whole, namely spiritually poor (Matthew 5: 3) and also socially poor (Luke 4: 18-19). God's concern for poverty is often emphasized in the Old Testament: (1) God became the liberator and protector of the poor. (2) through His prophets Allah condemns the oppression and injustice of the poor. (3) God's concern is manifested in His laws. The Lord Jesus in the Gospels proclaims the Jubilee Year movement. He loved the poor and condemned the oppression of the poor. His good news was proclaimed to the poor, blind, deaf, starving and lepers. The church must side with the poor because this is a reflection of God's solidarity with those who are suffering and are despised. God's love and defense of the poor. The COVID-19 pandemic and its impact on poverty must also be part of Christians together with other components of the nation to overcome it. The theological perspective that must be built is that God loves and is fair to those who are marginalized and poor. The church must be a part of the solution for any condition that occurs in society, nation and state
\end{abstract}

\begin{abstract}
ABSTRAK
Saat Virus COVID-19 menjadi pandemik dampaknya hampir disemua bidang kehidupan dan dirasakan oleh banyak negara di dunia ini. Salah satu dampaknya adalah meningkatnya angka kemiskinan. Di Indonesia sendiri diperkirakan 1, 2 juta akan terinfeksi dan akan menurunkan laju pertumbuhan ekonomi $1-4$ persen kemudian menaikan juga tingkat kemiskinan dari 9, 2 \% pada September 2019 ke 9,7\% pada akhir 2020. Ini berarti akan ada 1,3 juta orang yang akan jatuh miskin, dengan proyeksi terburuk tingkat kemiskinan akan menjadi $12,4 \%$ dan ini berarti bahwa 8,5 juta orang akan jatuh miskin. Dalam alkitab kemiskinan banyak disinggung, kemiskinan dalam PL adalah suatu keadaan yang buruk dan keji yang menghina martabat manusia dan berlawanan dengan kehendak Allah. Sedangkan dalam PB konsep Miskin dimaknai secara utuh yaitu miskin secara rohani (Matius 5:3) dan juga miskin secara sosial (Lukas 4: 18-19). Perhatian Allah kepada kemiskinan sering ditekankan dalam Perjanjian Lama: (1) Allah menjadi pembebas dan pelindung kaum miskin. (2) melalui nabi-nabi-Nya Allah mengutuk bentuk-bentuk penindasan dan ketidakadilan kepada orang-orang miskin. (3) perhatian Allah dinyatakan dalam hukum-hukum-Nya. Tuhan Yesus dalam Injil memproklamasikan gerakan Tahun Yobel. Dia mengasihi orang-orang miskin dan mengutuk penindasan terhadap kaum miskin. Kabar baik-Nya diproklamasikan kepada orang-orang miskin, buta, tuli, kelaparan, dan kusta. Gereja harus berpihak kepada kaum miskin karena hal ini merupakan refleksi dari solidaritas Allah kepada mereka yang menderita dan hina. Kasih dan pembelaan Allah kepada orang miskin. Pandemi COVID-19 dan dampaknya terhadap kemiskinan harus juga menjadi bagian umat Kristen secara bersama-sama dengan komponen bangsa yang lain untuk menangulanginya. Prespektif teologis yang harus dibangun adalah bahwa Allah mengasihi dan adil bagi mereka kaum marginal dan miskin. Gereja harus menjadi bagian dari solusi dari setiap kondisi apapun yang terjadi di dalam masyarakat, bangsa dan negara.
\end{abstract}

Keywords : Pandemi, Covid-19, Kemiskinan, Teologi Alkitabiah, Gereja, Umat Kristen 


\section{PENDAHULUAN}

Saat ini di perkirakan sudah jutaan orang di seluruh dunia terinfeksi penyakit Coronavirus 2019 (COVID-19). Di Indonesia sendiri diperkirakan 1,2 juta orang akan terinfeksi oleh COVID-19. Dampak yang paling besar dirasakan adalah resesi ekonomi secara global, jutaan orang akan jatuh dalam jurang kemiskinan. Indonesia pada awal proyeksi pertumbuhan ekonominya pada tahun 2020 adalah 5\%, karena COVID-19 berbagai penelitian memperkirakan pertumbuhan ekonomi Indonesia akan mengalami penurunan ke kisaran angka $1 \%$ sampai $4 \%$. Diperkirakan akan menaikan tingkat kemiskinan dari 9,2\% pada September 2019 ke 9,7\% pada akhir 2020. Hal ini menunjukan bahwa akan ada 1,3 juta orang yang akan jatuh miskin, dengan proyeksi terburuk tingkat kemiskinan akan meningkat menjadi 12,4\%, menyiratkan bahwa 8,5 juta orang akan menjadi miskin. ${ }^{1}$

Kepala BPS, Suhariyanto mengatakan bahwa "Pandemi Covid-19 membawa dampak yang luar biasa. Menganggu aktivitas ekonomi sehingga akhirnya mempengaruhi pendapatan masyarakat," kata Suhariyanto dalam konferensi pers virtual, Rabu (15/7). Lebih lanjut menurutnya selain pandemi Covid-19 yang menekan aktivitas ekonomi, terdapat tiga faktor lain yang turut menyumbang kemiskinan. Yakni pertumbuhan pengeluaran konsumsi rumah tangga yang mengalami perlambatan, terpuruknya sektor pariwisata, serta harga eceran komoditas pokok yang naik. ${ }^{2}$

Usaha pemerintah untuk mengurangi kemiskinan dalam satu dekade ini akan sia-sia dan implikasinya adalah Indonesia perlu memperluas program perlindungan sosialnya untuk membantu kaum miskin, baik yang baru miskin maupun yang telah ada sebelumnya. Lalu, bagaimana peran gereja yang juga terdampak dari masalah kemiskinan yang disebabkan oleh COVID 19 ini dalam berteologi dan praktisnya.

\section{KEMISKINAN DALAM ALKITAB}

\section{Pemahaman Kemiskinan Menurut Perjanjian Lama}

Dalam Alkitab kemiskinan memiliki arti pokok yaitu keadaan yang buruk dan keji yang menghina martabat manusia dan berlawanan dengan kehendak Allah. Hal ini nampak dalam katakata Alkitab yang dipakai untuk menyebut orang miskin dalam bahasa aslinya (Ibrani untuk PL dan Yunani untuk PB). ${ }^{3}$ Kemiskinan juga di pengaruhi kondisi secara sosial, politik, ekonomi masyarakat Israel terbagi menjadi dua yaitu masa Pra-monarki (sebelum Israel di bawah pemerintahan raja-raja) dan masa monarki (Israel dibawah pemerintahan raja-raja). ${ }^{4}$

Pada masa Pra-monarki masyarakat Israel hidup dalam apa yang disebut equal enjoyment (kondisi hidup yang merata). Pada masa ini ada bentuk organisasi yang bernama goel. Organisasi ini berfungsi sebagai penebus, penolong dan pelindung bagi saudaranya yang lemah. Jika salah satu di antaranya menjadi miskin dan menjual dirinya sebagai budak, maka goel inilah yang wajib

\footnotetext{
${ }^{1}$ https://www.smeru.or.id/id/content/dampak-pandemi-covid-19-terhadap-kemiskinan-estimasi-bagiindonesia (diakses 09/09/2020 jam 8.52)

${ }^{2}$ https://republika.co.id/berita/qdi4h5370/pandemi-covid19-jadi-penyebab-kemiskinan-meningkat (diakses 09/09/2020 jam 8.59)

${ }^{3}$ Malcom Brownlee, Tugas Manusia Dalam Dunia Milik Tuhan : Dasar Teologis Bagi Pekerjaan Orang Kristen Dalam Masyarakat, Jakarta : BPK Gunung Mulia, 2004. HIm.81

${ }^{4}$ Sukamto, Kemiskinan=Kutuk? Kepeduliaan Allah dan Tanggung Jawab Gereja Terhadap Kemiskinan, Yogyakarta : Penerbit ANDI, 2013. HIm. 27-28
} 
menebusnya (Im. 25: 47-49). ${ }^{5}$ Tetapi situasi ini berubah pada masa Monarki. Pada masa monarki terjadi kesenjangan secara ekstrem (Extreme Social Cleavange) antara dua kelas sosial, kelas penguasa dan kelas petani. Kesenjangan sosial antara yang kaya dan miskin tidak bisa dihindarkan dan akhirnya terbentuk kelas-kelas baru dalam masyarakat Israel. ${ }^{6}$ Ini terjadi kira-kira abad ke- 11 SM.

Timbul kesewenang-wenangan dari pihak yang merasa dirinya kuat dan sebagai penguasa. Kesewenang-wenangan ini tampak dalam bentuk-bentuk tindakan penindasan pada kaum lemah. Mereka menjual kaum yang lemah dengan sangat murah (Ams. 2: 6). Para penguasa menginjakinjak kepala orang lemah ke dalam debu dan membelokkan jalan orang sengsara (Ams. 2: 7); memberi suap kepada nabi untuk berhenti menyampaikan kebenaran, dan menyuap para hakim untuk membelokkan keadilan (Ams. 2: 12; 5: 12); dan memeras orang miskin (Ams. 4:1). ${ }^{7}$

\section{Jenis-jenis Kemiskinan}

Bahasa Ibrani dalam Perjanjian Lama mempunyai enam kata yang digunakan untuk menyebut orang miskin, yaitu : ('âní ), ('ebhyôn), (dal), ('anaw), (rash), dan ( mahsôr ). ${ }^{8}$ Berkaitan dengan pengunaan kata Ibrani untuk orang miskin, tidak ada perbedaan yang jelas dalam pengunaanya. Kata-kata tersebut di gunakan secara bergantian, bersinonim. ${ }^{9}$ Dan beberapa kali satu kata dapat memiliki arti yang berbeda. ${ }^{10}$

Kata miskin dalam Perjanjian Lama dapat dibagi sebagai berikut sesuai dengan jenis kemiskinannya:

\subsection{Kitab Pentateukh}

a. ('âní )

Kata 'âni adalah kata yang sangat umum di gunakan untuk orang miskin dalam PL. Kata ('âní ) berbeda arti dari kata ('ebhyôn), dan (dal) walaupun sering digunakan sebagai pararel. Kata ('âni) memiliki arti menunjukan pada kondisi ketidakmampuan atau keadaan yang menderita. ${ }^{11}$ Kata 'âní digunakan 7 kali dalam Pentateukh (Kel. 22: 25; Im. 19: 10; 23: 22; Ul. 15: $11 ; 24: 12,14,15)$ dan mempunyai arti jelas dikaitkan dengan kemiskinan secara ekonomi. Kata 'âni yang dipakai dalam kitab Pentateukh menunjuk kepada kesusahan yang berkaitan dengan kekurangan secara ekonomis. Secara keuangan orang ani dari hari ke hari berkekurangan (Ul. 24: 14, 15) dan secara sosial mudah menjadi obyek penindasan (Kel. 22: 23-25). Umat Allah diperintahkan membuka tangan lebar-lebar bagi kaum 'âní ( Ul.15: 11). ${ }^{12}$

\section{b. ('ebhyôn)}

Kata 'ebhyôn adalah maskulin tunggal. ${ }^{13}$ Kata ini muncul 9 kali dalam Pentateukh (Kel. 23: 6,11; Ul. 15: 4, 7 (2 kali), 9, 11 (2 kali); 24: 14). Dua kali kata ini digunakan bersama-sama

\footnotetext{
${ }^{5}$ Lihat Helmer Ringren, Goel, TDOT, Grand Rapids: Eerdmans, 1975. HIm. III.350f

${ }^{6}$ Sukamto, Ibid. HIm. 34

${ }^{7}$ Amos Sukamto, Keprihatinan Allah terhadap wong cilik (Prespektif Perjanjian Lama), Jurnal Pelita Zaman Vol. 13 No. 1. HIm. 30

${ }^{8}$ Sukamto, Op.Cit., hlm. 34

${ }^{9}$ Merril C. Tenney, ed., ZPEB, Vol.4, Grand Rapids, Michigan: Zondervan Publishing House, 1976. HIm. 819

${ }^{10}$ Misalnya dalam Rut 3: 10 menunjuk kepada orang miskin yang berasal dari petani kecil, sedangkan dalam kitab nabi-nabi kata Dal adalah obyek penindasan.

${ }^{11}$ Leonard J. Coppes, "'ani”, dalam TWOT, Vol. II, eds. R. Land Harris, Gleanson L. Archer, Jr., Waltke, Chicago: Moody Press, 1980. HIm. 683

12 Sukamto, Op.Cit. hlm. 37-38

${ }^{13}$ Benjamin Davidson, The Analytical Hebrew and Chaldee lexicon, Grand Rapids, Michigan: Zondervan

Publishing House
} 
dengan kata 'âní (Ul. 15: 11; 24: 14). Kata 'ebhyôn dalam Pentateukh menunjuk pada miskin secara materi. Kemungkinan ia kehilangan tanah warisan leluhurnya (Kel. 23: 11). Salah satu yang harus dapat penghapusan hutang (Ul. 15:1-11). Dapat disimpulkan 'ebhyôn dalam Pentateukh menunjuk kemiskinan secara ekonomi. ${ }^{14}$

c. (dal)

Kata dal muncul 48 kali dalam PL dan 5 kali dalam Pentateukh. Kata dal berasal dari Ugaritic yang berarti poor, needy, Kata dal pertama kali digunakan dalam Kejadian 41:1915. Fungsi kata dal dalam ayat ini adalah untuk mengambarkan kondisi lembu yang kurus dalam mimpi Firaun (Kej. 41: 19). ${ }^{16}$ Karena kata ini berkaitan dengan lembu kurus beberapa ahli bahasa menyimpulkan dalam perkembangan berikutnya kata dal digunakan untuk mengambarkan orang miskin. ${ }^{17}$

\subsection{Kitab Nabi-nabi}

\section{a. ('âní)}

Konsep 'âni dalam kitab nabi-nabi maknanya lebih berkembang jika dibandingkan dengan konsep 'âní dalam kitab Pentateukh. Dalam kitab nabi-nabi, makna kata 'âní bukan hanya menunjukan pada orang yang berkekurangan secara materi, melainkan lebih dari itu menunjukan pada mereka yang hak kepemilikan rumahnya diambil, ditindas, dan jatuh miskin. ${ }^{18}$

Orang 'âni ditindas oleh tua-tua atau penguasa. Mereka bukan hanya tidak meninggalkan sisa-sisa hasil panen bagi orang 'âni melainkan juga merampas harta orang 'âní ; mereka tidak memberi apa-apa kepada orang miskin, tetapi malah mengambil semua harta orang miskin. ${ }^{19}$

Orang kaya dan penguasa menghancurkan dan memusnahkan orang 'âní. Orang 'âní termasuk mereka yang mencari air, tetapi tidak menemukan (Am. 41: 17), lapar, tidak mempuunyai rumah, dan tidak mempunyai pakaian (Am. 58: 17).

\section{b. ('ebhyôn)}

Orang 'ebhyôn adalah orang yang: (1) secara fisik lemah dan tidak mempunyai rumah (Yes. 25: 4 band. Am.8:4), (2) Lapar dan haus (Yes. 32:6-7; 41:7;Yeh 16:49), (3) dianiaya oleh penguasa masyarakat dan struktur jahat lainya (Yes. 29:19; Yer. 2:34; 20:13; Yeh. 18:12 ; 12:29; Am. 4:1), (4) mendapat perlakuan hukum yang tidak adil (Am. 5:12 band Yes. 32:7; Yer. 22:16), (5) menjadi budak sebagai pembayaran atas utang mereka. ${ }^{20}$

\section{c. (dal)}

Kata dal menunjuk kepada mereka yang: (1) menderita karena eksploitasi dan penindasan (Am. 2:7, band 4:1), (2) dipaksa membayar pajak gandum kepada para tuan-tuan tanah (Am. 5:11). (3) mendapat perlakuan kejam dalam sistem utang perbudakan (Am. 8:6). (4) mendapat perlakuan hukum yang tidak adil (Yes. 10:2). (5) seseorang yang tidak punya apa-apa (Yer. 39:10). Sering kali kata dal juga digunakan untuk menunjukan pada kemiskinan secara rohani (Yer. 5:4 band Yes. $14: 30) .^{21}$

\footnotetext{
14 Sukamto, Op.Cit. HIm.39

${ }^{15}$ Tetapi kemudian tampaklah juga keluar tujuh ekor lembu yang lain, kulit pemalut tulang, sangat buruk bangunya dan kurus badanya; tidak pernah kulihat yang seburuk itu di seluruh tanah Mesir. (Kej. 41: 19). ${ }^{16}$ J. David Pleins, "Poor, Poverty," dalam ABD, Vol. V. Ed. David Noel Freedman, dkk, New York: Doubleday, 1992. HIm. 465

${ }^{17}$ Sukamto, op. Cit., hlm. 40

${ }^{18}$ D. E. Holwerda, "Poor," dalam ISBE, Vol. III, ed. Geoffrey W. Bromiley and Others, eds., Grand Rapids, Michigan: William B. Eerdmans Publishing Company, 1986., hlm. 905

19 J. A. Motyer, The Prophecy of Isaiah, Leicester LE 1 76p, UK: Intervarsity Press, 1973. HIm. 63

20 J. David Pleins, "poor, Poverty," HIm. 403

${ }^{21}$ Thomas J. Finley, Joel, Amos, Obadiah, HIm. 165
} 


\subsection{Kitab-Kitab Puisi}

\section{a. ('âní $)$}

Kata 'âní muncul 31 kali dalam Kitab Mazmur, dan digunakan untuk menunjuk pada : (1) penindasan terhadap seluruh bangsa ${ }^{22}$ (2) mereka yang diperlakukan tidak adil, yang tidak punya pengaruh atau status (Mzm. 82:2-4); (3) tidak mempunyai roti (Mzm. 132:15) (5) kaum yang mencari pembelaan kepada Yahweh untuk kemurahan dan pertolongan dalam memperjuangkan keadilan (10:1-2; 18:27; 25:16; 35:10; 34:7; 74:19; 102:1). Jadi, kata âní dalam Kitab Mazmur dapat diartikan sebagai penindasan secara fisik terhadap suatu bangsa. Mereka mengalami penindasan, mengalami kemiskinan baik secara material maupun spritual yang didemonstrasikan oleh pemazmur dengan ketergantungannya kepada Tuhan. ${ }^{23}$

\section{b. ('anaw)}

Kata 'anaw diartikan bukan hanya sebagai kemiskinan rohani, melainkan juga kemiskinan secara materi (Mzm. 76:9). Gillingham menyatakan: "The Parallelism of the 'afflicted' with 'those who seek him' indicates the poor are those with a spritual as well as aphysical hunger". (paraleisme antara "menderita" dan "mereka yang mencari Dia" menunjukan miskin disini adalah mereka yang miskin secara spiritual seperti kelaparan fisik). ${ }^{24}$

\section{c. ('ebhyôn)}

Kata ( 'ebhyôn ) menggambarkan: (1) mereka yang dianiaya oleh orang-orang jahat (72:1314; 37:14; 107:41; 112:9); (2) dikontraskan dengan orang kaya (49:2); (3) orang-orang yang dimiskinkan secara fisik $(35: 10 ; 86: 1 ; 140: 13)$. Jadi 'ebhyôn digunakan dalam Mazmur untuk menunjuk bukan hanya sesuatu yang bersifat materi, tetapi juga menunjukan pada kualitas baik secara moral maupun spritual. ${ }^{25}$

\section{d. dal}

Kata dal ini digunakan untuk menyebut orang-orang yang dalam komunitas direndahkan dalam arti secara fisik (82:3-4). Dalam Mazmur 113:7 kaum dal mendapat perlindungan secara khusus dari Allah. Zamani B. Kafang memahami kemiskinan dalam kitab Mazmur ke arah arti rohani, menerangkan bahwa kata dal digunakan untuk mengambarkan seseorang yang secara sosial, fisik, dan ekonomi lemah tidak berdaya. Kelemahan tersebut bukan hanya karena disebabkan sakit, melainkan juga karena status sosial dan ekonomi mereka. ${ }^{26}$

\subsection{Kitab-Kitab Hikmat}

\section{a. 'âní ; ebhyôn}

Kata 'âní dan 'ebhyôn di gunakan secara pararel dalam Amsal pasal 30-31 dan sangat jarang diluar pasal-pasal tersebut. Penggunaan kata tersebut untuk mengambarkan: (1) eksploitasi oleh para elit penguasa (Am. 30:14); (2) Raja Lemuel diperintahkan untuk membela hak orang 'ebhyôn dan 'âni di pengadilan (31:9), dan (3) istri yang cakap salah satunya diukur dengan kenyataan bahwa ia memberikan tanganya kepada yang tertindas, mengulurkan tanganya kepada yang miskin $(31: 20) .{ }^{27}$

\section{b. dal}

\footnotetext{
22 Sue Gillingham, "The Poor in The Psalms," dalam Exp Tim 100 (Oktober 1988-September 1989), HIm. 16

${ }^{23}$ Ibid., HIm. 18

${ }^{24} \mathrm{lbid}$.

$25 \mathrm{Ibid}$.

${ }^{26}$ Zamani B. Kafang, A Semantic and theological Investigation of The Concept of the "poor" in the Psalms, Ann Arbor, Michigan: University Microfilms, 1993. HIm. 83-84

${ }^{27}$ Lihat. Ibid. HIm. 64
} 
Kata dal dalam kitab Amsal menunjukan kepada orang-orang: (1) tanpa teman (19:4); situasi yang paling buruk yang ditemukan diantara orang miskin adalah ketika orang miskin menindas orang miskin lainya. (Ams. 28:3) ${ }^{28}$ Siapa menaruh belas kasihan kepada orang yang lemah ( $d a l$ ), memiutangi Tuhan, yang akan membalas perbuatanya (Ams. 19:17).

\section{c. rash, mahsôr}

Kata rash dalam Kitab Amsal menunjukan kepada: (1) seseorang yang berbicara memohon-mohon (18:23); (2) seseorang yang tidak punya teman (14:20; 19:7); (3) orang miskin karena hasil kemalasanya (10:4). Kata mahsôr menunjuk pada: (1) kemiskinan sebagai hasil kemalasan $(6: 11 ; 14: 23 ; 21: 5 ; 24: 34)$; (2) kemiskinan sebagai akibat dari hidup yang boros (21:17).

Maka dapat disimpulkan Perjanjian Lama mengunakan kata 'âní, 'ebhyôn, dal, 'anaw, rash dan mahsôr untuk mengekspresikan kondisi kemiskinan. Makna kata ini berkembang tergantung pada konteks historisnya. Konsep 'âni dan 'ebhyôn dalam kitab Nabi-nabi artinya lebih berkembang bila dibandingkan dengan konsep yang sama dalam Kitab Pentateukh. Dalam kitab para Nabi tidak hanya menunjukan kekurangan materi, tetapi lebih dari itu, mereka juga ditindas, dicabut hak individualnya, dan dimiskinkan. Dalam kitab Puisi dan Kitab Hikmat dikaitkan dengan orang-orang yang menderita secara fisik, mereka yang tertindas, baik secara materi maupun spritual yang ditunjukan dengan ketergantunganya kepada Allah. Kata dal menunjuk pada kelas rendah di masyrakat Israel. Kitab Amsal menggunakan kata khusus untuk kemiskinan yaitu rash, dan mahsôr yang digunakan untuk kemiskinan akibat kemalasan dan hidup yang boros. ${ }^{29}$

\section{Kriteria Kemiskinan}

Ada tiga kelompok yang biasanya dikategorikan sebagai orang miskin dalam perjanjian lama, yaitu: janda, anak yatim, dan orang asing (Im. 19: 10; 23:22; Ayb. 29:12-13; Za. 7: 9-10). ${ }^{30}$ Donald E. Gowan mendefinisikan janda, anak yatim, dan orang asing sebagai berikut:

Janda adalah seseorang yang mengalami pengalaman perubahan keberuntungan dari rasa aman ke ketidaktentuan yang tak terencanakan dan tak diingini. Anak yatim piatu tidak mampu menolong diri mereka karena keterbatasan kondisi fisik mereka. Orang pendatang adalah orang yang tidak mempunyai apa-apa. ${ }^{31}$

Meskipun tidak selalu miskin, mereka biasanya akan menjadi miskin karena mereka tidak mempunyai kesempatan yang sama seperti rata-rata orang laki-laki di Israel. Janda dan anak yatim biasanya bergantung atas kebaikan budi orang lain karena secara struktur sosial, yaitu didominasi laki-laki, usia dan kemampuan fisik, mereka adalah kelompok yang lemah. Mereka akan lebih mudah menjadi miskin dibandingkan kelompok lain. Karena orang lain biasanya akan mudah memperdaya mereka, dan akses mereka dalam masyarakat biasanya sangat lemah. ${ }^{32}$

Masalah yang paling buruk bagi kaum janda, anak yatim adalah ketidakberdayaan mereka sehingga meskipun tidak miskin, mereka cenderung akan menjadi miskin, dan yang miskin bertambah miskin.

Maka dapat disimpulkan kriteria orang miskin menurut PL adalah sebagai berikut: (1) kekurangan kebutuhan hidup; (2) secara sosial seorang yang tidak berdaya dan mudah menjadi obyek penindasan; (3) kaum yang ditindas, diperkosa hak-hak kewajaran kemanusiaanya; (4) tidak

\footnotetext{
${ }^{28}$ David Pleins, "Poverty in the social world of the wise", JSOT 37, 1987, HIm. 67.

${ }^{29}$ Sukamto, Op. Cit., HIm. 53-54

30 ibid., HIm. 35

${ }^{31}$ Donald E. Gowan," Wealth and Poverty in the Old Testament The Case of the Widow, the Orphan, and the Sojourner", Interpretation XLI:4, 1987. HIm. 344

32 Ibid., hlm. 343-344
} 
mendapat perlakuan hukum secara adil; (5) korban dari pembunuhan yang semena-mena oleh para penguasa; (6) penerima santunan dari orang lain; (7) kaum yang dilecehkan lembaga-lembaga pengadilan; (8) kaum yang menderita karena eksploitasi dan penindasan dari kaum kuat; (9) kaum yang masih mampu membiayai kehidupan sehari-hari akan tetapi karena ketidakberdayaannya sehingga mudah ditindas oleh para penguasa; (10) kaum yang mempunyai padang gandum tetapi tidak mampu membayar pajak; (11) kaum yang mengadu tentang penderitaan kemiskinannya kepada Allah untuk mendapat keadilan; dan (12) kaum yang miskin yang disebabkan oleh kemalasan dan hidup yang boros. ${ }^{33}$

\section{Faktor-faktor Penyebab Kemiskinan}

Faktor penyebab kemiskinan di dalam Perjanjian Lama adalah karena Kemalasan (Ams. 6: 9-11; 24: 30-34; 19:15), kemabukan, kebodohan, dan kerakusan (Ams. 23: 20-21 ; 21: 17 ; 13 : 18,28; 28: 19); atau malapetaka (Kel. 10: 4-5) ${ }^{34}$ Penyebab yang paling sering disebut dalam PL adalah keserakahan, pemerasan dan penindasan, yang dikutuk Allah dan Nabi-nabi Israel.

Juga perbuatan-perbuatan yang menyebabkan kemiskinan atau merugikan orang miskin, yaitu: penggunaan timbangan dan takar yang palsu (Hos. 12:8; Am. 8:15; Mi. 6:10-11), penyerobotan tanah (Mi. 2:1-3), pengadilan yang tidak adil (Am. 5:7; Yer. 22:13-17; Mi. 3:4-11), perbudakan (Neh. 5:1-5; Am. 2:6; Mi. 3:1-2; 6:12; Yer. 22: 13-17) dan pajak yang tidak adil. ${ }^{35}$

\section{B. Pemahaman Kemiskinan Menurut Perjanjian Baru}

Kondisi secara sosial ekonomi di Palestina pada abad pertama dalam masa sangat suram. Kecuali sekelompok kecil pemilik tanah atau tuan-tuan tanah di Galilea, mayoritas penduduk Palestina hidup dengan pendapatan yang pas-pasan atau minim. ${ }^{36}$ Mayoritas besar orang Yahudi pada zaman Yesus di Galilea, Transyordania dan Yudea tinggal dikota-kota kecil, bukan kota-kota besar seperti Tiberias dan Yerusalem. ${ }^{37}$ Beberapa ahli menganggap bahwa Galilea relatif terisolasi, penduduknya hidup bersama di desa-desa kecil yang jauh dari komunitas-komunitas kota. ${ }^{38}$ Keadaan tempat tinggal mengambarkan kemiskinan pada masa itu, Rumah -rumah dibangun dengan dinding-dinding yang tidak merata dari balok-balok kayu basal, yang tidak cukup kuat untuk menopang lantai kedua. Ruang-ruang dibawah sangat kecil dengan ventilasi yang buruk dan jendela-jendela yang sempit. ${ }^{39}$

Para petani menanggung pajak yang sangat besar. Mereka tidak hanya harus membayar upeti kepada Roma tetapi juga harus membiayai bangunan-bangunan mewah Herodes di Yudea dan diberbagai kota Yunani bahkan sampai ke Anthokia. Para petani ini membayar pajak, sewa dan kemudian pinjaman dan bunganya sendiri, bila beruntung mereka bisa mempunyai tanah, tempat mereka terus bisa bertahan. ${ }^{40}$

\footnotetext{
${ }^{33}$ Amos Sukamto, Op. Cit., HIm. 35

${ }^{34}$ S. Nababan, Iman dan Kemiskinan, Jakarta: BPK Gunung Mulia, 1966. HIm. 8-11

${ }^{35}$ Malcom Brownlee, Op. Cit., HIm. 82

${ }^{36}$ Eduard Lohse, The New Testament Environment, Penterjemah Joh. E Steely, Nashville: Abingdon, 1976, HIm. 147

37 John Stambaugh dan David Balch, Dunia Sosial Kekristenan Mula-mula, Jakarta: Bpk Gunug Mulia, 2004, HIm. 92-93

38 Ibid. HIm. 105

${ }^{39}$ Log. Cit.

40 Ibid., HIm. 104
} 
Pada waktu Herodes Antipas berkuasa, dia mendirikan kota yang baru di Danau Galilea dan menamakanya sesuai dengan nama kaisar, yaitu Tiberias. Kemudian menjadi ibu kota yang baru. Penduduknya campuran, tetapi kebanyakan Yahudi. Konstitusi kota mengikuti cara Yunani. Kota ini kemudian dikuasai oleh Agripa I, lantas dialihkan kepada para prokurator Romawi dari Yudea, dan kemudian pada tahun 61 Masehi kepada Agripa II. Kebanyakan kota-kota pada masa itu adalah poleis yaitu memiliki pemerintahan sendiri. Di Kota Yamnia, Yope, Seforis dan Teberias, orang-orang Yahudi memiliki hak yang sama dan jumlah mereka lebih banyak daripada yang non Yahudi. Namun, di Yerusalem adalah satu-satunya kota di mana orang-orang bukanYahudi tidak mempunyai hak-hak sipil. ${ }^{41}$

\section{Jenis-Jenis Kemiskinan Menurut Perjanjian Baru}

\subsection{Kitab Kisah Para Rasul}

Menurut Kisah para rasul kata $\chi \eta \rho \alpha(C h \bar{e} r a)$ muncul 3 kali yang biasanya dalam literarur Alkitab dikategorikan sebagai miskin. Dalam Kisah Para Rasul 6:1 disebutkan kelompok janda Hellenis yang dilupakan dalam pelayanan meja. Mereka datang dari diaspora, tinggal di Palestina dan berbicara dalam bahasa Yunani. ${ }^{42}$ Ada kemungkinan para janda Hellenis ini terputus dengan kerabatnya pada waktu diaspora dan sekarang hanya bergantung pada orang-orang Ibrani lokal (yang berbicara dalam bahasa Aram), baik secara ekonomi maupun dukungan sosial. ${ }^{43}$ Para janda inilah adalah korban ketidakadilan, miskin, dan harus bergantung pada kebaikan dan kedermawanan orang lain untuk keperluan ekonomi dan kehidupan sehari-hari. (Kis. 9:39, 41).

\subsection{Surat-Surat Paulus}

Dalam Surat-Surat paulus kata miskin muncul 7 kali. Ketujuh pemunculan kata miskin itu adalah untuk kata ptwco.j (ptōchos) (Rm. 15:26; 2 Kor. 6:10; Gal. 2:10; 4:9;) ptwcei,a (ptōcheia) muncul 2 kali (2 Kor. 8:2, 9); dan pe,nhsin (penēin) muncul satu kali (2 Kor. 9:9). ${ }^{44}$ Dalam pernyataan Paulus di Roma 15: 26, "Sebab Makedonia dan Akhaya telah mengambil keputusan untuk menyumbangkan sesuatu kepada orang miskin diantara orang-orang kudus di Yerusalem". Ada perdebatan diantara para sarjana, apakah kata ptwco.j (ptōchos) indentik dengan Gereja Yerusalem atau dengan sebuah kelompok dari gereja tersebut atau kata ptwco.j (ptōchos) berarti miskin secara finansial atau nama khusus bagi kelompok orang saleh mula-mula. ${ }^{45}$ William Sanday dan Arthur C. Headlam menyimpulkan bahwa dari Kisah Para Rasul dapat dilihat bahwa ada orang miskin yang bergantung pada diakonia gereja. ${ }^{46}$

Kata ptwco.j (ptōchos) yang muncul dalam Galatia 2:10 yang dapat dipahami dengan dua cara, baik dalam arti miskin secara ekonomi maupun miskin dalam kesalehan (anawim, poor). Juga

\footnotetext{
41 Ibid., HIm.102-103

42 John R. W. Stott, The Message of Acts BST, England: Intervarsity Press, 1991, HIm. 120

${ }^{43}$ Sukamto, Op. Cit., HIm. 78

${ }^{44}$ Dalam Perjanjian Baru kata pokok dalam bahasa Yunani untuk miskin adalah ptwco.j dan pe,nh. kata ptwco.j menunjukan kepada mereka yang sangat miskin, menjadi peminta-minta dan membutuhkan pertolongan. la tidak dapat menolong diri sendiri tanpa bantuan orang lain. Sedangkan kata pe,nh menunjukan kepada orang-orang yang bisa hidup dengan apa yang dimilikinya, tetapi harus bekerja keras dengan tangannya.

${ }^{45}$ Sukamto, Op. Cit., HIm. 79

${ }^{46}$ William Sanday dan Arthur C Headlam, A Critical and Exegetical Commentary on The Epistel to the Romans ICC, Edinburgh: T.\&T. Clark Ltd, 1980, HIm. 412
} 
ada yang memahaminya sebagai kemiskinan kronis. ${ }^{47}$ Kata ptwco.j (ptōchos) yang muncul dalam tulisan-tulisan Paulus dapat disimpulkan bahwa kata ini digunakan Paulus lebih mengarah kepada kemiskinan secara ekonomi daripada miskin secara rohani.

\subsection{Kitab Yakobus}

Kitab Yakobus menggunakan dua kata untuk menggambarkan kondisi kemiskinan, yaitu tapeino.j (tapeinos) (Yak. 1:9; 4:16) dan . ptwco.j (ptōchos), (Yak. 2:2, 3, 5, 6). Kata tapeino.j (tapeinos) digunakan untuk menggambarkan: (1) kecuali situasi yang sulit seseorang atau masyarakat juga status sosial yang rendah. ${ }^{48}$ (2) Dalam LXX (Septuaginta) kata ini digunakan untuk menggambarkan; kondisi penindasan oleh kekuasaan politik bangsa lain dan kekuasaan militer. $^{49}$

Secara ringkas dapat dikatakan bahwa kata tapeino.j (tapeinos) dan kata ptwco.j (ptōchos), menunjuk kepada kemiskinan secara sosial maupun ekonomi. Lebih dari itu, mereka ditindas oleh orang-orang kaya dan korban ketidakadilan.

\section{Kriteria Kemiskinan}

Pembagian kelompok status sosial pada masa awal PB dapat di kategorikan sebagai berikut: (1) kelompok orang kaya. Mereka yang masuk dalam kelompok ini adalah keluarga atau kerabat raja; imam aristokrat; pedagang-pedagang; tuan-tuan tanah; sanhendrin. ${ }^{50}$ (2) Kelas Menengah. Yang termasuk golongan ini adalah para Imam. (3) orang miskin, budak, dan pekerja harian. ${ }^{51}$

Orang miskin, budak dan pekerja harian adalah mereka yang benar-benar miskin, yang tidak mempunyai harta milik dan menunjang kehidupanya dengan kerja borongan di dok-dok kapal, di proyek bagunan Romawi atau di ladang. Ladang. ${ }^{52}$

Para pengemis, diantara para pengemis ini adalah mereka yang sakit, buta, lumpuh dan para penderita kusta, yang memainkan peranan sedemikian penting dalam laporan Kitab-Kitab Injil dalam pelayanan Yesus. ${ }^{53}$

Orang asing juga tersingkirkan menjadi masyarakat pinggiran menjadi korban prasangka yang bersifat budaya. Status yang paling rendah adalah budak. Dianggap lebih rendah daripada manusia. Hukum Romawi menganggapnya sebagai sebuah harta milik dan ribuan budak yang bekerja sebagai kelompok-kelompok berpindah-pindah di kapal-kapal, ladang-ladang, proyek-

\footnotetext{
${ }^{47}$ Frederic Rendall, The Epistle to the Galatians, in EGT, Vol. III, ed. W. Robertson Nicoll, Grand Rapids, Michigan: WM. B. Eerdmans Publishing Company, 1974. HIm. 101

${ }^{48}$ Walter Grundmann, tapeino.j in TDNT, Vol. VIII, ed. Gerhard Friedrich, Pen. Geoffrey W. Bromley, Grand Rapids, Michigan: WM. B. Eerdmans Publishing company, 1971, HIm. 3

49 Ibid.

${ }^{50}$ Kelompok sanhendrin adalah kelompok Saduki dan loyal kepada Roma. Mereka para pemimpin agama yang mencari untung dari perdagangan dan Bait Allah.

${ }^{51}$ Sukamto, Op.Cit., HIm. 74

52 John Stambaugh, Op. Cit., HIm. 134

53 Ibid.
} 
proyek pembangunan jalan, atau tambang diperlakukan tidak lebih daripada sebuah barang dagangan. ${ }^{54}$

\section{Faktor-Faktor Penyebab Kemiskinan dalam PB}

Faktor- faktor penyebab terjadinya kemiskinan pada masa PB adalah: (1) Perang di Palestina pada abad kedua dan pertama Sebelum Masehi. Akibat peperangan ini banyak masyarakat yang terusir dari tanah kelahiran mereka karena kemiskinan dan kesengsaraan yang mereka derita. ${ }^{55}$ (2) penyebab terpenting munculnya kondisi seperti itu adalah beban pajak yang ditetapkan terlalu tinggi. Di bawah pemerintahan Siria, sepertiga dari hasil panen, setengah dari hasil anggur dan hasil bumi harus diberikan kepada Raja. ${ }^{56}$

Pada masa pemerintahan Romawi ditetapkan pajak sebesar seperempat dari hasil panen. Disisi lain, pada saat Romawi berkuasa diperkerjakan para pemungut cukai yang mengumpulkan pajak tidak langsung, mirip pajak penjualan seperti pajak makanan, bahan bakar minyak, dan lainlain. Pada proses pengumpulannya, pemungut cukai akan mengumpulkan sebanyak mungkin yang ia dapat peras dari masyarakat (lebih dari apa yang ditentukan Pemerintah Romawi). Para pemungurt pajak ini akan menyetor pajak sesuai dengan ketentuan yang berlaku, sedangkan sisanya untuk kepentingan pribadi (mis. Luk. $3: 13 ; 19: 1-9$ ). ${ }^{57}$

Sebagai akibat beban pajak seperti itu, angka kemiskinan meningkat dan banyak orang hanya mempunyai sedikit tanah dan perlahan-lahan kehilangan satu-satunya harta milik yang sangat hakiki bagi mereka karena hutang mereka atas beban pajak yang tinggi. ${ }^{58}$ Meskipun kondisi ekonomi membaik pada waktu Palestina berada di bawah dominasi Kekaisaran Roma, perkembangan keadaan ini hanya menguntungkan sedikit segmen kelompok sosial tertentu, yaitu kelas atas. Kondisi ekonomi masyarakat biasa atau kebanyakan bahkan menjadi lebih buruk. ${ }^{59}$.

Pada masa kini, kata ini juga dipakai bagi orang yang ditindas dan di marginalkan oleh para penguasa, para pemimpin agama, dan orang-orang kaya. karena kemiskinanya, secara total bergantung kepada Allah, mencari pembelaan dan keadilan hanya kepada Allah. Orang miskin berteriak kepada Yahweh untuk mendapatkan kemurahan hati dan keadilan. Janda, anak yatim, dan musafir biasanya di kategorikan sebagai orang-orang miskin.

\section{Prespektif Teologis terhadap Pandemi Covid 19 dan Kemiskinan}

Kemiskinan adalah hal persoalan yang dihadapi oleh banyak negara dan semakin pelik masalahnya karena pandemic COVID-19 saat ini semakin menambah angka kemiskinan secara drastic. Amos Sukamto menyatakan bahwa dalam masyrakat gereja kemiskinan memang telah menjadi salah satu masalah sentral yang dibicarakan dalam Teologi Kontemporer Kristen dan menjadi sebuah pertanyaan yang kontroversial. ${ }^{60}$ Menurutnya menjadi pertanyaan kontroversial

\footnotetext{
54 Ibid., HIm. 135

${ }^{55}$ Eduard Lohse, The New Testament environment, Pen. John E. Steely, Nashville: Abingdon Press, 1976, hlm. 147

56 lbid.

${ }^{57}$ Bruce J. Malina, The New Testament World: Insight From Cultural Anthropology, Atlanta: John Knox Press, 1981, HIm. 81

58 Sukamto, Kemiskinan=Kutuk?, HIm. 73

59 Ibid.

${ }^{60}$ Amos Sukamto , Agama dan Kemiskinan: Prespektif Kristen dalam Jurnal Studi Pembangunan, Kemasyrakatan \& Lingkungan, Vol. 2, No. 2/2000; 61
} 
karena ambigunya arti kemiskinan dalam Alkitab. Menurut penulis arti kemiskinan sudah jelas dalam Alkitab.

Dari keseluruhan pembahasan di atas dapat ditarik kesimpulan sebagai berikut: berdasarkan survei penggunaan istilah miskin dalam Alkitab, bahwa konsep kemiskinan berkembang berdasarkan konteks historis. Pada masa pra-monarki, kata ptōchoi hanya mempunyai konotasi miskin secara ekonomi, yaitu kekurangan materi. Namun, pada masa monarki (Kerajaan Israel), kata ptōchoi memiliki arti lebih luas.

Pada masa kini, kata ini juga dipakai bagi orang yang ditindas dan di marginalkan oleh para penguasa, para pemimpin agama, dan orang-orang kaya. karena kemiskinanya, secara total bergantung kepada Allah, mencari pembelaan dan keadilan hanya kepada Allah. Orang miskin berteriak kepada Yahweh untuk mendapatkan kemurahan hati dan keadilan. Janda, anak yatim, dan musafir biasanya di kategorikan sebagai orang-orang miskin.

Dalam Injil konsep miskin dimaknai secara utuh. Mereka tidak hanya miskin secara rohani tetapi juga miskin secara sosial. Miskin secara rohani seperti dalam Injil Matius 5: 3, maksud dari miskin rohani disini adalah sederhana dan penuh hormat terhadap hal-hal rohani, rendah hati karena sadar hidup spritual mereka bukan apa-apa. Mereka sepenuhnya mengandalkan Allah, sebab membutuhkan-Nya. Ibarat manusia yang kosong, yang ingin diisi oleh Allah. ungkapan miskin didalam roh mengacu kepada manusia yang merendah secara rohani, yang tidak melawan dan tidak memberontak, orang yang miskin dalam roh sekaligus rendah hati, sabar dan lembut.

Arti miskin secara sosial seperti dalam Injil Lukas 4: 18-19, miskin secara sosial (politik, materi, bahkan keagamaan) yaitu mereka yang ditolak, dimarginalkan, ditindas, dan diasingkan. Para pemimpin agama mengolongkan mereka pada orang-orang yang tidak dapat mengikuti aturan keagamaan. Misalnya, tidak dapat mengikuti hari sabat karena pekerjaan mereka, contohnya gembala. Orang -orang ini juga tidak bisa mengikuti regulasi agama (persembahan pada Bait Allah) karena kemiskinan mereka.

Perhatian Allah kepada kemiskinan sering ditekankan dalam Perjanjian Lama: (1) Allah menjadi pembebas dan pelindung kaum miskin. (2) melalui nabi-nabi-Nya Allah mengutuk bentuk-bentuk penindasan dan ketidakadilan kepada orang-orang miskin. (3) perhatian Allah dinyatakan dalam hukum-hukum-Nya. Tuhan Yesus dalam Injil memproklamasikan gerakan Tahun Yobel. Dia mengasihi orang-orang miskin dan mengutuk penindasan terhadap kaum miskin. Kabar baik-Nya diproklamasikan kepada orang-orang miskin, buta, tuli, kelaparan, dan kusta.

Dalam Perjanjian Baru yang terdapat dalam Injil Matius $26: 11$ Yesus mengatakan bahwa orang miskin akan selalu ada dan dalam Kis. 2:43-47; bnd. Kis 5:1-11 pada masa para rasul, banyak pengikut Kristus yang menjual harta bendanya dan kemudian membagikannya kepada orang miskin. Gereja atau umat Kristen harus berpihak kepada orang-orang yang menderita dan berjuang sebagai pihak dalam kesetiakawanan dengan mereka yang terpinggirkan.

Gereja harus berpihak kepada kaum miskin karena hal ini merupakan refleksi dari solidaritas Allah kepada mereka yang menderita dan hina. Kasih dan pembelaan Allah kepada orang miskin. Dalam Matius 25: 42-45 Yesus menyamakan diri-Nya dengan mereka yang menderita yaitu yang lapar, haus dan dalam penjara. Ajaran Yesus melalui Khotbah di Bukit (Mat. 5-7) secara kontekstual juga harusnya membuat orang Kristen yang kekurangan atau miskin untuk tidak minder, merasa rendah diri, tidak meminta-minta untuk mengasihani diri sendiri, karena iman Kristen yang membawa mereka menjadi ahli waris kerajaan sorga Ini harus menjadi kesaksian dan misi gereja yaitu memberdayakan kaum marginal dan memperjuangkan struktur yang tidak adil.. 
Jika saat ini masih banyaknya orang-orang miskin dan akan semakin bertambah karena Pandemi COVID-19, bukan menjadi alasan untuk tidak mewarisi kerajaan sorga, tetapi juga iman dan kepercayaan orang Kristen yang menjadi bagian dalam pewarisan kerajaan sorga. Melalui pemahaman ini, maka orang Kristen yang memiliki kekayaan mau berbagi dengan mereka yang miskin untuk menjadi saluran berkat dan perwujudan pemeliharaan Tuhan atas umat-Nya.

Kemiskinan juga erat kaitannya dengan soal keadilan, ini bukan soal tentang ekonomi namun tentang miskin secara rohani. Orang Kristen yang melimpah secara jasmani (kekayaan) menyadari bahwa itu semua merupakan berkat dan kepercayaan Tuhan. Orang Kristen harus menjadi pengelola atas harta bendanya dengan menyalurkan kembali berkat yang diterimanya kepada mereka yang miskin. Orang Kristen jangan menjadi miskin dalam hal kerelaan dalam memberi. Berdasarkan keyakinan teologis untuk setia kepada perjanjian Allah, kita dapat menentukan sikap terhadap ketidakadilan sosial ekonomi. Karena ini bukanlah hanya isu soail, politik dan moral. Tetapi juga bagian dari iman kita kepada Yesus Kristus dan Integritas gereja.

\section{KESIMPULAN}

Pandemi COVID-19 dan dampaknya terhadap kemiskinan harus juga menjadi bagian umat Kristen secara bersama-sama dengan komponen bangsa yang lain untuk menangulanginya. Prespektif teologis yang harus dibangun adalah bahwa Allah mengasihi dan adil bagi mereka kaum marginal dan miskin. Gereja harus menjadi bagian dari solusi dari setiap kondisi apapun yang terjadi di dalam masyarakat, bangsa dan negara.

Seperti gereja mula-mula yang menolong mereka yang lemah dan miskin. Saling berbagi supaya terciptanya keseimbangan. Karena Yesus pun datang untuk mereka yang lemah dan tersisih. Kasih yang nyata haruslah menjadi bagian hidup bagi orang yang beriman. Sebagai orang yang beriman kita harus memperjuangkan membantu mereka yang lemah yang ada di sekitar kita.

Wujud nyata dari kasih bukanlah hanya dari kata-kata tetapi melalui Tindakan nyata, orang Kristen atau gereja harus menjadi bagian dari solusi. Gereja atau umat Kristen memiliki kesempatan yang besar untuk ikut perduli secara holistic untuk mengatasi kemiskinan yang disebabkan oleh Pandemi COVID-19 ini, yaitu peduli dan membantu secara nyata mereka yang miskin secara sosial terlebih lagi yang miskin secara rohani. 


\section{DAFTAR PUSTAKA}

Brownlee, Malcom. Tugas Manusia Dalam Dunia Milik Tuhan : Dasar Teologis Bagi Pekerjaan Orang Kristen Dalam Masyarakat, Jakarta : BPK Gunung Mulia, 2004

Coppes, Leonard J. “'ani”, dalam TWOT, Vol. II, eds. R. Land Harris, Gleanson L. Archer Davidson,Benjamin. The Analytical Hebrew and Chaldee lexicon, Grand Rapids, Michigan: Zondervan Publishing House

Gillingham, Sue. "The Poor in The Psalms," dalam Exp Tim 100 (Oktober 1988-September 1989)

Gowan, Donald E. " Wealth and Poverty in the Old Testament The Case of the Widow, the Orphan, and the Sojourner", Interpretation XLI:4, 1987

Grundmann,Walter. tapeino.j in TDNT, Vol. VIII, ed. Gerhard Friedrich, Pen. Geoffrey W. Bromley, Grand Rapids, Michigan: WM. B. Eerdmans Publishing company, 1971

Holwerda,D. E. “Poor,” dalam ISBE, Vol. III, ed. Geoffrey W. Bromiley and Others, eds., Grand Rapids, Michigan: William B. Eerdmans Publishing Company, 1986

https://republika.co.id/berita/qdi4h5370/pandemi-covid19-jadi-penyebab-kemiskinanmeningkat ( diakses 09/09/2020 jam 8.59)

https://www.smeru.or.id/id/content/dampak-pandemi-covid-19-terhadap-kemiskinanestimasi-bagi-indonesia ( diakses 09/09/2020 jam 8.52)

J. A. Motyer, J. A. The Prophecy of Isaiah, Leicester LE 1 76p, UK: Intervarsity Press, 1973 Kafang, Zamani B. A Semantic and theological Investigation of The Concept of the "poor" in the Psalms, Ann Arbor, Michigan: University Microfilms, 1993

Lohse, Eduard. The New Testament environment, Pen. John E. Steely, Nashville: Abingdon Press, 1976

Malina, Bruce J.The New Testament World: Insight From Cultural Anthropology, Atlanta: John Knox Press, 1981

Nababan, S. Iman dan Kemiskinan, Jakarta: BPK Gunung Mulia, 1966.

Pleins, David. "Poverty in the social world of the wise", JSOT 37, 1987

Pleins, J. David. “Poor, Poverty,” dalam ABD, Vol. V. Ed. David Noel Freedman, dkk, New York: Doubleday, 1992

Rendall, Frederic. The Epistle to the Galatians, in EGT, Vol. III, ed. W. Robertson Nicoll, Grand Rapids, Michigan: WM. B. Eerdmans Publishing Company, 1974 
Sanda, William dan Headlam, Arthur C. A Critical and Exegetical Commentary on The Epistel to the Romans ICC, Edinburgh: T.\&T. Clark Ltd, 1980

Stambaugh, John dan Balch, David. Dunia Sosial Kekristenan Mula-mula, Jakarta: Bpk Gunug Mulia, 2004

Stott, John R. W. The Message of Acts BST, England: Intervarsity Press, 1991

Sukamto, Amos , Agama dan Kemiskinan: Prespektif Kristen dalam Jurnal Studi Pembangunan, Kemasyrakatan \& Lingkungan, Vol. 2, No. 2/2000

Sukamto, Amos. Keprihatinan Allah terhadap wong cilik (Prespektif Perjanjian Lama), Jurnal Pelita Zaman Vol. 13 No. 1

Sukamto, Kemiskinan=Kutuk? Kepeduliaan Allah dan Tanggung Jawab Gereja Terhadap Kemiskinan, Yogyakarta : Penerbit ANDI

Tenney, Merril C. ed., ZPEB, Vol.4, Grand Rapids, Michigan: Zondervan Publishing House, 1976. 